\title{
National survey of radionuclide gastric emptying studies
}

\author{
A House MD FRCPC, MC Champion MB FRCPC FRCP(UK), M Chamberlain MD FRCPC
}

\begin{abstract}
A House, MC Champion, M Chamberlain. National survey of radionuclide gastric emptying studies. Can J Gastroenterol $1997 ; 11(4): 317-321$. A survey was mailed to all institutions in Canada licensed to use radiopharmaceuticals. Questions addressed meal type; mode of preparation; and means, ranges and SD of emptying times. Seventy-eight per cent of 222 facilities responded, including all 55 teaching centres. Eighty-five per cent of teaching and $56 \%$ of nonteaching centres perform solid phase gastric emptying studies (GES). The majority use ${ }^{99 \mathrm{~m}} \mathrm{Tc}$ sulphur colloid (Tc-SC) added to eggs before cooking as the standard meal. Twenty-five per cent of teaching and $21 \%$ of nonteaching centres perform liquid phase GES. Most use a watery solution of ${ }^{111} \mathrm{In}$ diethylenetriamine pentaacetic acid. Gastric emptying for solid phase GES, expressed as time for $50 \%$ emptying (mean $t_{1 / 2}$ ), varied from 42 to 105 mins for centres using the Tc-SC egg meal. Twenty-eight per cent of teaching centres used $\pm 2 \mathrm{SD}$ to define their normal range, $26 \%$ used \pm 1 SD, $6 \%$ used \pm 1.5 SD, and $40 \%$ did not know the number of SD used. Twenty per cent of nonteaching centres used \pm 2 SD, $12 \%$ used \pm 1 SD and $68 \%$ did not know how many SD were used. For liquid phase GES, mean $t_{1 / 2}$ varied from 20 to 60 mins. Eighteen per cent of centres used healthy volunteers to establish or validate normal ranges. There is substantial variability among the normal ranges for radionuclide solid and liquid phase GES in both teaching and nonteaching centres across Canada. A minority of facilities have established or validated their own normal ranges in healthy volunteers. There is a need for a more standardized protocol and range of normal, with internal validation by each institution.
\end{abstract}

Key Words: Gastric emptying, Nuclear medicine, Radionuclides, Surveys

$\mathrm{T}$ he study of gastric emptying originates from as far back as 1833, when William Beaumont published his observations on gastric emptying and secretion in Alexis St Martin, a patient with a gastric fistula (1). Griffith and colleagues (2) were the first to use radionuclide methods in 1966. They used a ${ }^{51} \mathrm{Cr}$-labelled meal, and intermittent

\section{Enquête nationale sur les tests de vidange gastrique isotopiques}

RÉSUMÉ : Un questionnaire a été envoyé à tous les établissements canadiens autorisés à utiliser des produits radiophamaceutiques. Les questions portaient sur le type de produits, le mode de préparation, les moyennes, l'éventail des valeurs et les écarts-types (é.-t.) des temps de vidange. Soixante-dix-huit pour cent des 222 établissements ont répondu, y compris les 55 établissements d'enseignement universitaire. Quatre-vingt-cinq pour cent et $56 \%$ des établissements d'enseignement universitaire et communautaire respectivement procèdent à des tests de vidange gastrique en phase solide. La majorité utilisent un colloïde de ${ }^{99 \mathrm{~m}}$ technitium soufré (Tc-SC) ajouté à des oeufs avant la cuisson d'un repas normal. Vingt-cinq pour cent des établissements d'enseignement et $21 \%$ des établissements communautaires utilisent le test de vidange gastrique en phase liquide. La plupart utilisent une solution aqueuse de ${ }^{111}$ indium-DTPA. La vidange gastrique pour la phase solide, exprimée sous la forme du temps requis pour une vidange à $50 \%$ ( $\mathrm{t}_{1 / 2}$ moyen), variait de 42 à 105 minutes pour les centres utilisant le repas à base d'oeufs marqués au Tc-SC. Vingt-huit pour cent des établissements d'enseignement utilisaient \pm 2 é.-t. pour définir leur éventail normal, $26 \%$ utilisaient \pm 1 é.-t., $6 \% \pm 1,5$ é.-t. et $40 \%$ ne savaient pas quelle valeur d'é.t. était utilisée. Vingt pour cent des établissements communautaires utilisaient \pm 2 é.-t., $12 \%$ utilisaient \pm 1 é.-t. et $68 \%$ ne savaient pas combien d'é.t. étaient utilisés. Pour la phase liquide, le $t_{1 / 2}$ moyen variait de 20 à $60 \mathrm{~min}$ utes. Dix-huit pour cent des centres utilisaient des volontaires en bonne santé pour établir ou valider l'éventail des valeurs normales. On note une variété substantielle entre les éventails de valeurs normales pour les phases solide et liquide des repas isotopiques, tant dans les établissements d'enseignement que dans les hôpitaux communautaires au Canada. Une minorité d'établissements avaient fixé et validé leurs propres éventails de valeurs normales chez des volontaires en bonne santé. Il faut voir à l'application d'un protocole plus standardisé et à l'établissement de valeurs normales avec validation interne pour chaque établissement.

Department of Medicine, Ottawa General Hospital; Departments of Medicine and Nuclear Medicine, Ottawa Civic Hospital, Ottawa, Ontario Correspondence and reprints: Dr MC Champion, GI Unit A1, Ottawa Civic Hospital, 1053 Carling Avenue, Ottawa, Ontario K1Y 4E9

Received for publication October 28, 1996. Accepted February 20, 1997 
TEACHING CENTRES

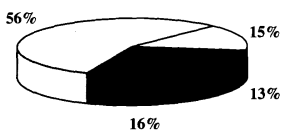

$16 \%$

\section{NONTEACHING CENTRES}

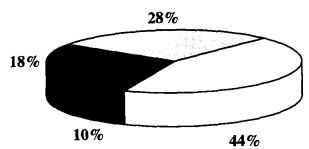

$44 \%$

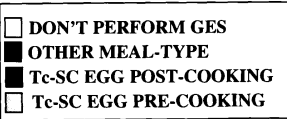

Figure 1) Meal type by centre for solid phase gastric emptying studies (GES). Tc-Sc ${ }^{99 m}$ Tc sulphur colloid

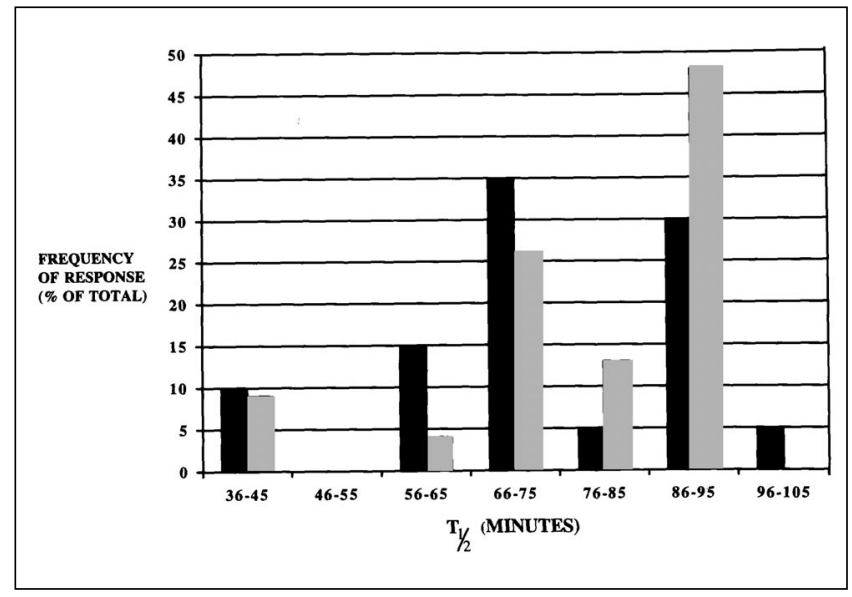

Figure 2) Mean time for the stomach to empty 50\% of a radiolabelled meal $\left(t_{1 / 2}\right)$ for solid phase gastric emptying studies reported by teaching centres (black bars) and nonteaching centres (grey bars) using ${ }^{99 m} \mathrm{Tc}$ sulphur colloid added to eggs before cooking as the test meal

which the radioisotope is added before or after cooking (4). Malmud et al (5) compared a number of test meals and described the superiority of in vivo liver with respect to stability in gastric juice, although other meal types, including Tc-SC egg, were quite satisfactory. Tc-SC egg was found to have $82 \%$ binding at $3 \mathrm{~h}$.

Current gastroenterology and nuclear medicine literature reveals great variability in technique, meal type, preparation and normal ranges for both solid and liquid phase gastric emptying studies (GES) (6-10). To evaluate further the variability in performance and interpretation of radionuclide GES in Canada, a survey was conducted.

\section{MATERIALS AND METHODS}

A survey in French and English was mailed to all 222 hospitals and institutions licensed by the Atomic Energy Control Board for the use of radiopharmaceuticals in humans. The surveys were to be completed by the nuclear medicine department head or their designate. Eight weeks later the sur- vey was resent to institutions that had not yet responded. In addition, 55 of the institutions were identified as being university affiliated (teaching centres), and those who did not respond from that group were surveyed by telephone. This distinction was meant to increase the yield of responses from those centres, which were believed to be more likely to perform GES.

The survey was a one-page questionnaire in both French and English, which included questions on the performance of GES, meal type and mode of preparation, various imaging characteristics, reported means and ranges of normal, number of SD included in the normal range, and whether the centres had validated their own ranges in healthy controls.

\section{RESULTS}

Responses were obtained from 173 of the 222 centres, for an overall response rate of $78 \%$. A $100 \%$ response rate was achieved from the 55 teaching centres.

As seen in Figure 1, 85\% of teaching centres and $56 \%$ of nonteaching centres perform solid phase GES. Of those who perform the tests, $66 \%$ of teaching centres and $50 \%$ of nonteaching centres use Tc-SC added to eggs before cooking as the standard meal. The second most frequent meal-type is prepared by adding Tc-SC to eggs after they have been cooked. A variety of other meal types are used by the remaining centres, including technetium-labelled chicken liver, technetium albumin bound to egg and radiolabelled Ensure (Ross Laboratories). Twenty-five per cent of teaching centres and $21 \%$ of nonteaching centres perform liquid phase GES, the majority using ${ }^{111}$ In-diethylenetriamine pentaacetic acid in a watery solution.

Figure 2 shows the frequency of responses for the mean time it takes for the stomach to empty $50 \%$ of a radiolabelled meal $\left(t_{1 / 2}\right)$ considered to be normal by both teaching and nonteaching centres who use Tc-SC added to eggs before cooking as the test meal. Thirty-five per cent of teaching centres considered a normal mean $\mathrm{t}_{1 / 2}$ to be 66 to $75 \mathrm{mins}$, but responses varied from 42 to $105 \mathrm{mins}$ for the same test meal.

Figure 3 shows the upper limits of $\mathrm{t}_{1 / 2}$ from teaching and nonteaching centres using Tc-SC added to eggs before cooking. Five per cent of teaching centres report an acceptable upper limit of 46 to 55 mins, and 10\% report an upper limit of 116 to 125 mins, with a variety of responses in between.

Figure 4 compares upper limits of normal $t_{1 / 2}$ among groups using Tc-SC added to eggs before or after cooking, and demonstrates the variation in what was considered a normal test result, regardless of meal type.

The lag phase of gastric emptying is felt to reflect the initial mixing of food in the stomach before emptying begins. Of all centres that perform solid phase GES, 9.7\% responded that they take into account the lag phase when determining $t_{1 / 2}$. The questionnaire did not ask how each centre compensated for this phenomenon.

For liquid phase GES, normal mean $t_{1 / 2}$ ranged from 20 to 60 mins. The upper limit of normal for $t_{1 / 2}$ varied from 25 to 70 mins.

All centres were asked how many SDs from the mean 


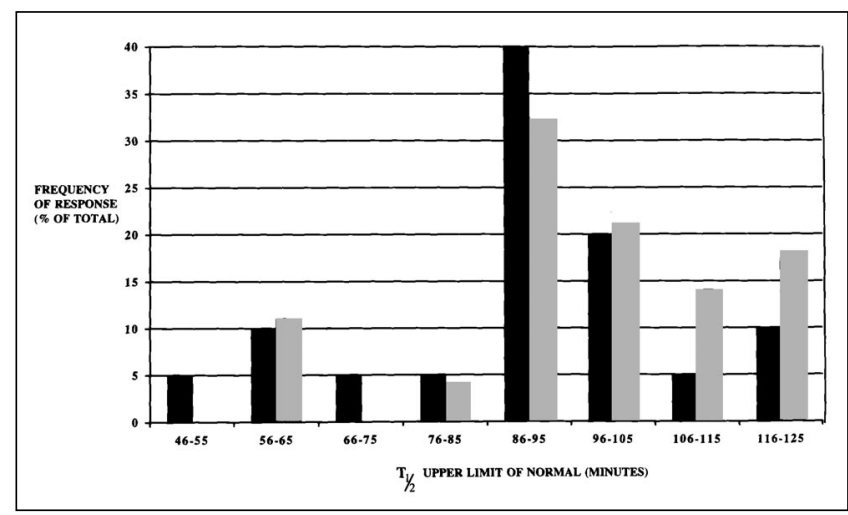

Figure 3) Upper limit of normal for normal time for the stomach to empty $50 \%$ of a radiolabelled meal $\left(t_{1 / 2}\right)$ for solid phase gastric emptying studies reported by teaching centres (black bars) and nonteaching centres (grey bars) using ${ }^{99 m} \mathrm{Tc}$ sulphur colloid added to eggs before cooking as the test meal

were contained in their normal ranges. Twenty-eight per cent of teaching centres reported using $\pm 2 \mathrm{SD}$ to define their normal range, $26 \%$ used \pm 1 SD, $6 \%$ used $\pm 1.5 \mathrm{SD}$ and the remaining $40 \%$ did not know or report the SD used. This contrasts with results from nonteaching centres, where $20 \%$ used \pm 2 SD, $12 \%$ used \pm 1 SD and the remaining $68 \%$ did not know or report the SD contained in their normal range.

In total, $32 \%$ of teaching centres and $11 \%$ of nonteaching centres reported using their own healthy volunteers to either establish or validate the range used by their facility. The remainder described a variety of sources, including neighbouring institutions, textbooks, computer software and journal articles. Several departments mentioned one particular reference that served as their standard (5).

\section{DISCUSSION}

This survey revealed that there is substantial variability in what is considered by both teaching and nonteaching centres across Canada to be a normal rate of gastric emptying. When the data were examined from centres using the same test meal for solid phase GES, considerable variation was observed in what was considered a normal $t_{1 / 2}$. Examining the data in Figure 3, which shows the upper limits of normal, a patient with a $t_{1 / 2}$ of 96 mins would be considered normal by roughly one-third of the centres performing the tests, and abnormal by the remaining two-thirds. Although reports of mean $t_{1 / 2}$ seemed to cluster around specific values (leading to the bimodality observed in Figure 2, for example) we were unable to correlate these responses to technical factors such as body position or imaging characteristics.

There are a number of legitimate reasons why the acceptable range for $t_{1 / 2}$ could vary among centres. The pace of gastric emptying is influenced by many variables. Temperature, volume, acidity, osmolarity, particle size, caloric content, hypertonic solutions, or solutions containing fat or certain amino acids can alter gastric emptying via neural and hormonal pathways $(5,8,11-21)$. Several authors have found the mean $t_{1 / 2}$ to be considerably longer in women than in men $(22,23)$, and sex steroids may help account for such differ-

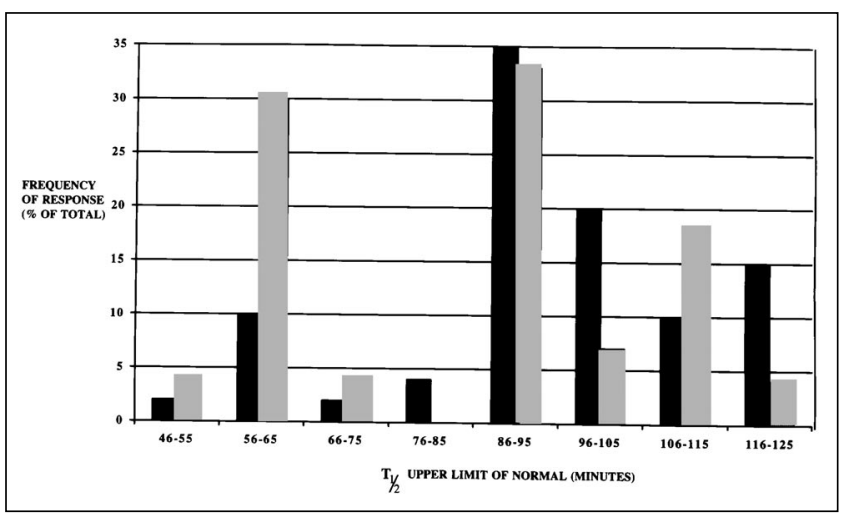

Figure 4) Upper limit of normal for normal time for the stomach to empty $50 \%$ of a radiolabelled meal $\left(t_{1 / 2}\right)$ for solid phase gastric emptying studies reported by all centres using $99 \mathrm{~m} T \mathrm{c}$ sulphur colloid added to eggs before cooking (black bars) and after cooking (grey bars) as the test meal

ences (24). Smoking may also affect the rate of gastric emptying (20). One group found the mean $t_{1 / 2}$ to vary from 77 to 277 mins when $300 \mathrm{~g}$ meals were compared with $1692 \mathrm{~g}$ meals in 10 healthy males (25). Kao et al (10) found age to be an important factor in liquid phase, but not in solid phase, gastric emptying, with Chinese adults above the age of 60 years having a significantly prolonged $t_{1 / 2}$ compared with their younger counterparts.

Centres also differ in their imaging techniques, with patients being studied in a variety of positions. Body posture may influence pace of gastric emptying (26), though some authors have not found this (27). Different acquisition types are used, namely dynamic imaging, where gamma counts are continuously measured, or static imaging, where counts are intermittently measured. Katz et al (28) used both dynamic and static studies to compare anterior imaging with geometric mean imaging (anterior and posterior cameras). They found that anterior imaging methods resulted in statistically longer mean $t_{1 / 2}$ than geometric mean corrected data. Christian et al (25) found a similar discrepancy for each meal size they examined. The importance of this difference, however, was addressed by Kelley et al (29), who found that despite the overestimation by anterior-only imaging, only $2.2 \%$ of patients would be misdiagnosed with prolonged gastric emptying, when compared with the 'gold standard' of geometric mean imaging.

Solid phase gastric emptying includes two phases: the initial lag phase, followed by a more rapid emptying period. Eleven of 113 centres performing solid phase GES take into account lag phase when determining gastric emptying time. Large differences have been described in lag phase calculations depending on the use of mathematic versus physiological methodology (30). Recently, a computerderived nonlinear curve fitting function with an initial lag phase followed by an exponential decay was found to be more reliable than a monoexponential curve with no lag phase (31). Katz et al (28) found that the lag phase varies with imaging technique, from 6 mins with geometric mean-corrected static acquisition to 19 mins with anterior- 
only continuous imaging. The variable use of lag phase calculations in Canadian centres is reflected in our survey results.

Finally, tests of gastric emptying are known to vary among tests in the same individual. Brophy et al (32) found that the coefficient of variation for repeated tests approaches was $50 \%$.

With all of the previously mentioned influences upon gastric emptying and its measurement, we are concerned that only a minority of both teaching and nonteaching centres in Canada have established their own normal ranges in healthy volunteers, or have used such volunteers to validate the ranges they have chosen from the literature or adopted from other centres. Several centres quote a review article by Malmud et al (5) as their source for a normal $t_{1 / 2}$ range, when in fact these authors provide data as percentage emptying at fixed times, and not as time for $50 \%$ gastric emptying. It is also interesting that nearly half of the nonteaching centres do not perform GES. We can only speculate that there is not a significant demand for this test in the regions serviced by nonteaching institutions, or that these centres do not perform enough tests to feel comfortable with their interpretation or reliability, or that the demand is not great enough to justify the time and expense of establishing appropriate methodology.

\section{CONCLUSIONS}

Given the degree of variability that this survey demonstrates in the performance and interpretation of GES in Canada, there is a need for a more standardized protocol and range of

\section{REFERENCES}

1. Horowitz M, Collins PJ, Shearman, DJC. Disorders of gastric emptying in humans and the use of radionuclide techniques. Arch of Intern Med 1985;45:467-72.

2. Griffith GH, Owen GM, Kirkman S, Shields R. Measurement of rate of gastric emptying using Chromium-51. Lancet 1966;i:1244-5.

3. Meyer JH, MacGregor IL, Gueller R, Martin P, Cavalieri R. ${ }^{99 m}$ Tc-tagged chicken liver as a marker of solid food in the human stomach. Dig Dis 1976;21:296-304.

4. Martin JL, Beck WJ, McDonald AP, Carlson GM, Mathias JR. ${ }^{99 m}$ Tc-labelled solid-phase meal: a quantitative clinical measurement of human gastric emptying. J of Clin Gastroenterol 1983;5:315-9.

5. Malmud LS, Fisher RS, Knight LC, Rock E. Scintigraphic evaluation of gastric emptying. Semin Nucl Med 1982;12:116-25.

6. Ziessman HA, Fahey FH, Collen MJ. Biphasic solid and liquid gastric emptying in normal controls and diabetics using continuous acquisition in LAO view. Dig Dis Sci 1992;37:744-50.

7. Ang ES, Lim TC, Goh AS, Toh HJ, Sundram FX. Radionuclide measurement of liquid and solid gastric emptying in normal subjects in Singapore. Ann Acad Med Singapore 1986;15:511-5.

8. Chaudhuri TK, Fink S: Update: pharmaceuticals and gastric emptying. Am J Gastroenterol 1990;85:223-30.

9. Urbain JLC, Vekemans R, Bouillon R, et al. Characterization of gastric antral motility disturbances in diabetes using a scintigraphic technique. J Nucl Med 1993;34:576-81.

10. Kao CH, Lai TL, Wang SJ, Chen GH, Yeh SH. Influence of age on gastric emptying in healthy Chinese. Clin Nucl Med 1994;19:401-4.

11. Sun WM, Houghton LA, Read NW, Grundy DG, Johnson AG. Effect of meal temperature on gastric emptying of liquids in man. Gut 1988;29:302-5.

12. Paraskevopoulos JA, Houghton LA, Eyre-Brooke I, Johnson AG, Read NW. Effect of composition of gastric contents on resistance to emptying of liquids from stomach in humans. Dig Dis Sci 1988;33:914-8. normal, with internal validation by each institution. We recognize, however, the difficulty in procuring adequate numbers of volunteers for validation of this diagnostic test and, indeed, any test that is subject to influence by so many variables. Rather than suggest a specific protocol, we recommend, as do others (33), that standard conditions be adhered to both in the establishment of a normal range and in the subsequent testing of patients. These recommendations are listed in the Appendix. In addition, it may be valuable to correct for gamma attenuation related to the position of the stomach relative to the small intestine and anterior movement of food by using lateral or oblique imaging, or using the geometric mean method.

ACKNOWLEDGMENTS: We greatly appreciate the cooperation of the many individuals who took the time to complete this survey, and who spoke with the investigators by telephone. Without their efforts, this survey would not have been possible.

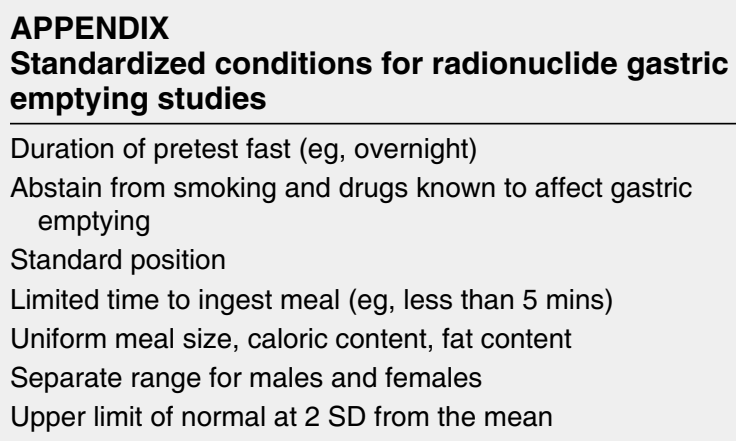

13. Hunt JN, Stubbs DF. The volume and energy content of meals as determinants of gastric emptying. J Physiol 1975;245:209-25.

14. Hunt JN. The site of receptors slowing gastric emptying in response to starch in test meals. J Physiol 1960;154:270-6.

15. Fisher M, Hunt JN. Effects of hydrochlorides of amino acids in test meals on gastric emptying. Digestion 1977;16:18-22.

16. Kroop HS, Long WV, Alavi A, Hansell JR. Effect of water and fat on gastric emptying of solid meals. Gastroenterology 1979;77:997-1000.

17. Moore JG, Christian PE, Coleman RE. Gastric emptying of varying meal weight and composition in man: Evaluation by dual liquid- and solid-phase isotopic method. Dig Dis Sci 1981;26:16-22.

18. Minami H, McCallum RW. The physiology and pathophysiology of gastric emptying in humans. Gastroenterology 1984;86:1592-610.

19. Meyer JH, Elashoff J, Porter-Fink V, Dressman J, Amidon GL. Human postprandial gastric emptying of 1-3-millimeter spheres. Gastroenterology 1988;94:1315-25.

20. Rock E, Malmud L, Fisher RS. Motor disorders of the stomach. Medical Clinics of North America 1981;65:1269-89.

21. Shafer RB, Levine AS, Marlette JM, Morley JE. Do calories, osmolality, or calcium determine gastric emptying? Am J Physiol 1985;248:R479-83.

22. Wright RA, Krinsky S, Fleeman C, Trujillo J, Teague E. Gastric emptying and obesity. Gastroenterology 1983;84:747-51.

23. Hermansson G, Sivertsson R. Gender-related differences in gastric emptying rate of solid meals. Dig Dis Sci 1996;41:1994-1998.

24. Hutson WR, Roehrkasse RL, Wald A. Influence of gender and menopause on gastric emptying and motility. Gastroenterology 1989;96:11-7.

25. Christian PE, Moore JG, Sorenson JA, Coleman RE, Weich DM. Effects of meal size and correction technique on gastric emptying time: studies with two tracers and opposed detectors. J Nucl Med 1980;21:883-5. 
26. Moore JG, Datz FL, Christian PE, Greenberg E, Alazraki, N. Effect of body posture on radionuclide measurements of gastric emptying. Dig Dis Sci 1988;33:1592-5.

27. Hancock BD, Bowen-Jones E, Dixon R, Testa T, Dymock IW, Cowley DJ. The effect of posture on the gastric emptying of solid meals in normal subjects and patients after vagotomy. Br J Surg 1974;61:945-9.

28. Katz N, Toney MO, Heironimus JD 2nd, Smith TE. Gastric emptying. Comparison of anterior only and geometric mean correction methods employing static and dynamic imaging. Clin Nucl Med1994:19:396-400.

29. Kelley A, Park H-M, Appledorn CR. Radionuclide gastric emptying: correlation between the anterior-only and the geometric mean method. J Nucl Med Tech 1993;21:65-8.
30. Yung BCK, Sostre S. Lag phase in solid gastric emptying: comparison of quantification by physiological and mathematical definitions. J Nucl Med 1993;34:1701-5.

31. Ehrenpreis ED, Zaitman D. Improved computer analysis of solid phase gastric emptying scans. Am J Gastroenterol 1996;91:674-9.

32. Brophy CM, Moore JG, Christian PE, Egger MJ, Taylor AT. Variability of gastric emptying measurements in man employing standardized radiolabeled meals. Dig Dis Sci 1986;31:799-806.

33. Akkermans LMA, van Isselt JW. Gastric motility and emptying studies with radionuclides in research and clinical settings. Dig Dis Sci 1994;39(Suppl):95S-96S. 


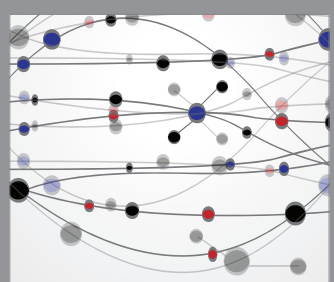

The Scientific World Journal
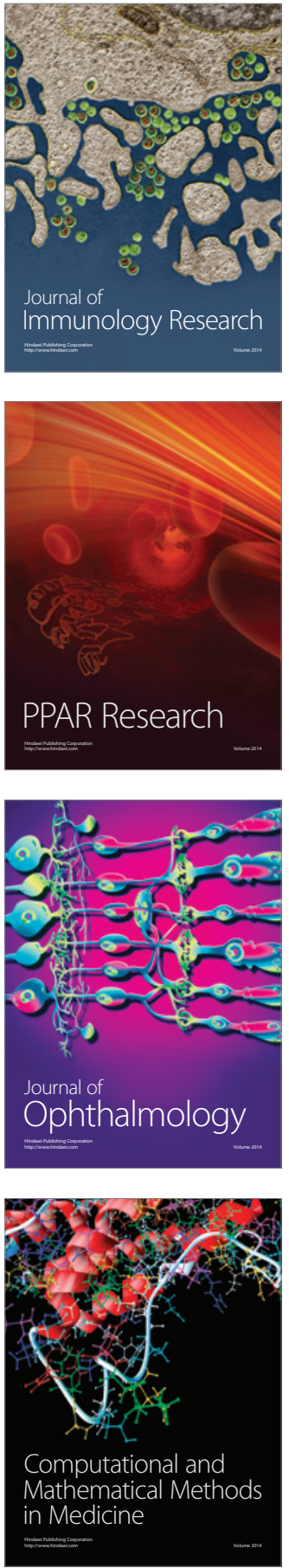

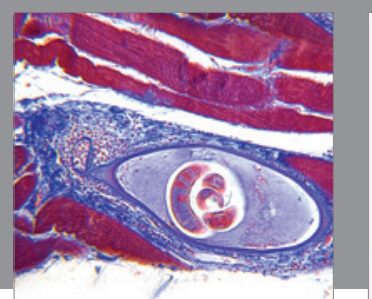

Gastroenterology Research and Practice

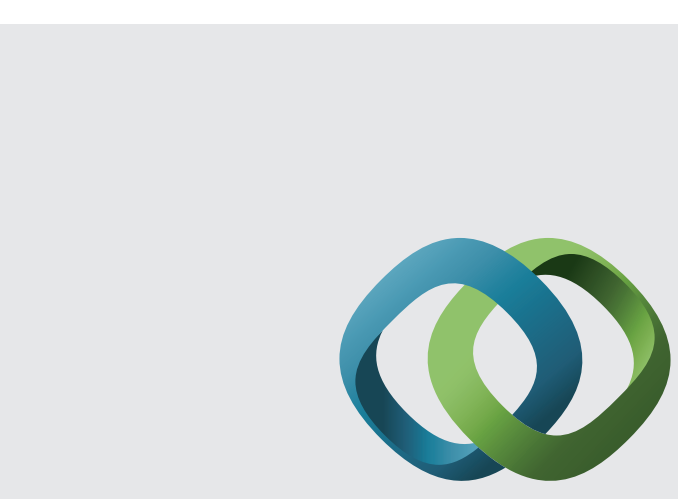

\section{Hindawi}

Submit your manuscripts at

http://www.hindawi.com
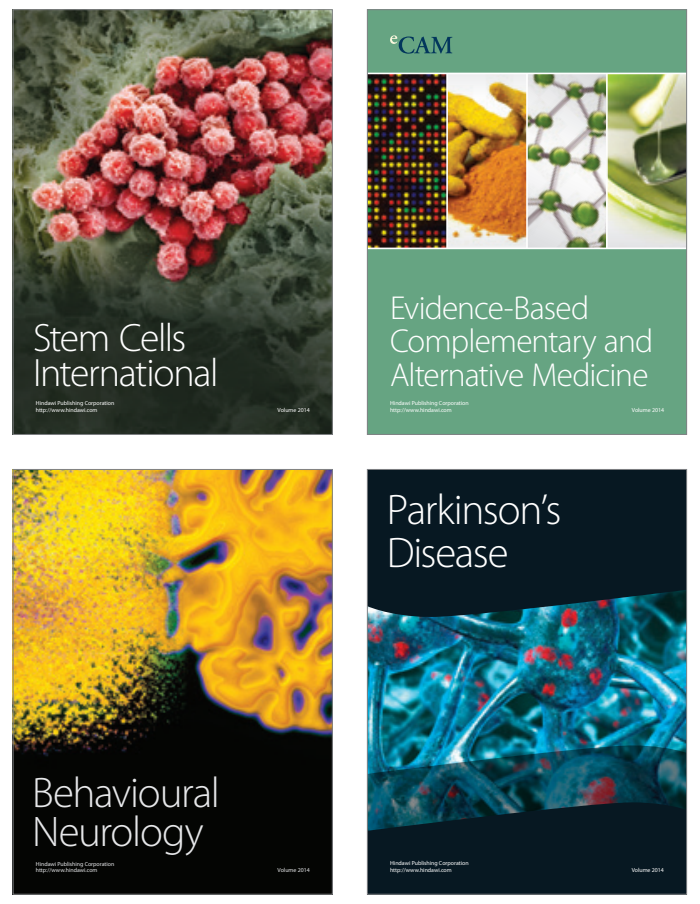
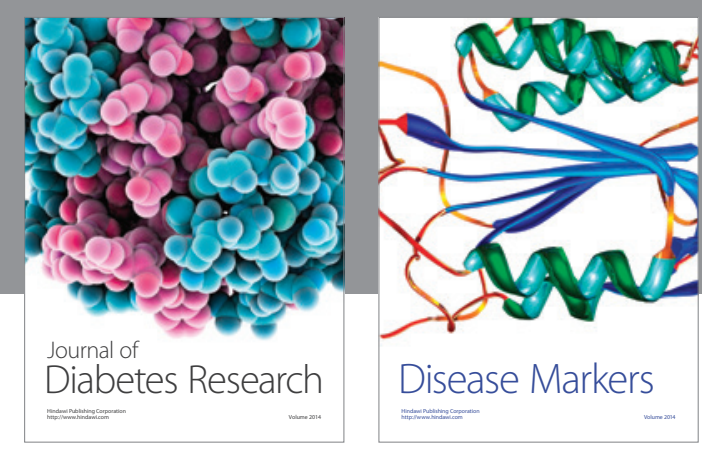

Disease Markers
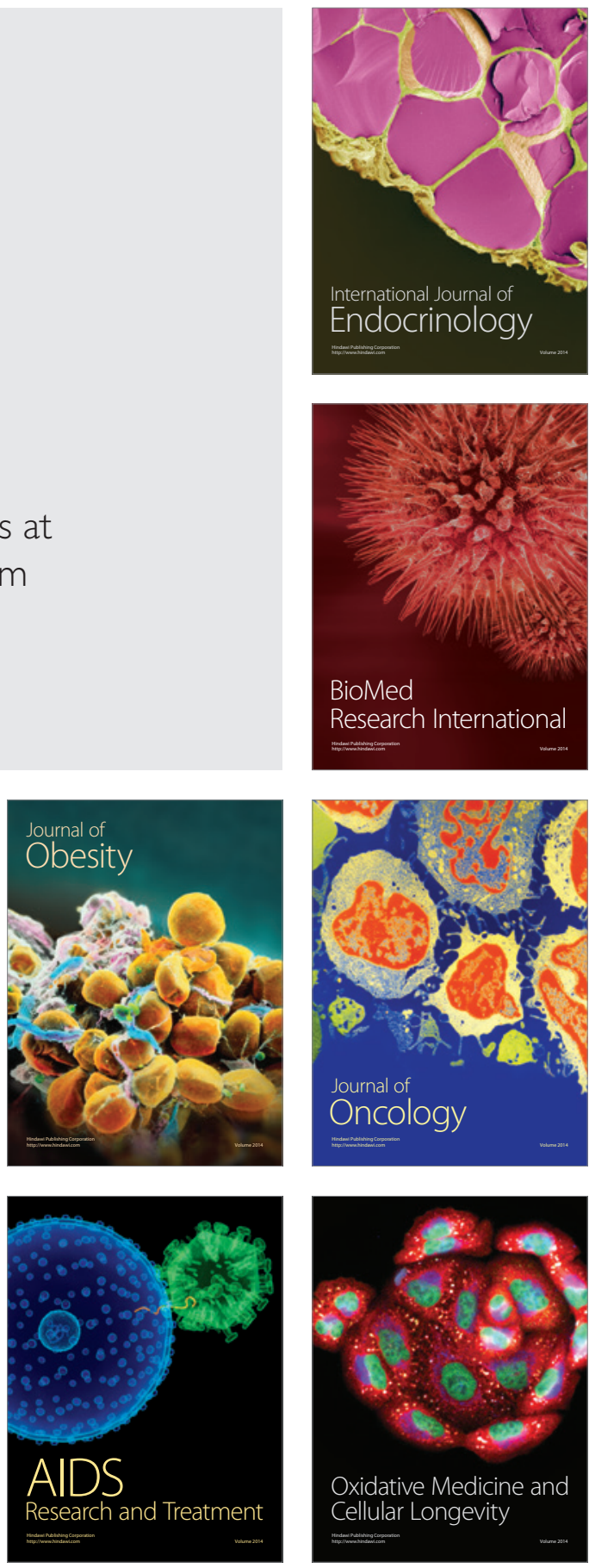